\title{
Sociology of Terrorism: A Brief History and Overview of the Islamic State of Iraq and Syria's (ISIS) Propaganda Wing from a Socio-Educational Perspective
}

\section{Mohammad Husni Abumelhim}

\author{
Associate Professor, \\ Department of Sociology and Social Work, \\ Ajloun University College, \\ Al-Balqa Applied University, \\ Ajloun, Jordan; \\ Corresponding Author
}

\section{Ramzy Mahmoud Radaideh}

Lecturer,

King Talal School of Business Technology, Princess Sumaya University for Technology, Amman, Jordan

\section{Esra'a Omar Abu-Alkeshek}

\author{
Assistant Professor, \\ Department of Education, Arab Open University, \\ Amman, Jordan
}

DOI: https://doi.org/10.36941/jesr-2022-0o61

\begin{abstract}
This study aimed at providing a brief overview of ISIS's ideology and origins as starting points for an analysis of its propaganda strategy. How did ISIS utilize its ideological propaganda wing to achieve its socioeducational goals? An intrinsic case study is used to provide an overview of ISIS's key multi-lingual propaganda documents and media modes. It is these documents and modes of media that ISIS uses as primary sources for its propaganda strategy, which is employed through vocabulary reinforcement, in addition to piece-meal usage of Qur'an and Hadith. Through the intrinsic case study, this study illustrates precisely how ISIS's ideology is reflected through both content and form. Since ISIS's inception as an offshoot of Al-Qaeda in Iraq (AQI), ISIS has learned to constantly reposition and remarket itself as a needed response to the needs of the umma. It is only by understanding the periodicals that ISIS has developed over time that one can do justice in delving into ISIS's strategy of sociolinguistic terrorism.
\end{abstract}

Keywords: Sociology of Terrorism; ISIS; Propaganda; Dabiq 


\section{Introduction}

This study systematically traces the roots of ISIS as a terrorist organization while giving an overview of the structure of its propaganda wing. Understanding the backdrop from which ISIS operates, including its history, will help those concerned with the global rise of terror to better understand how to mitigate ISIS's reemergence. To do this, this study uses an intrinsic case study to delineate ISIS's origins while incorporating a desk review of ISIS's most prominent propaganda mediums to shed light on its multi-pronged approach to ideological promotion. In addition to providing an overview of ISIS's propaganda wing - including Al-Hayat Media Center (the foreign-language media arm responsible for producing Dabiq) - this study will briefly compare Al-Hayat's most prominent periodicals with Dabiq to help serve to clarify Dabiq's unique target audience and political, socioeducational recruiting aims.

\section{Study Problem}

The problem of this study is determined in exploring that ISIS is utilizing its ideological propaganda wing to achieve the socio-educational goals through providing an overview of ISIS's propaganda wing including Al-Hayat Media Center as well as by comparing Al-Hayat's most prominent periodicals with Dabiq to help serve to clarify Dabiq's unique target audience and political, socio-educational recruiting aims.

\section{Study Question}

The study seeks to illustrate the following question: How did ISIS utilize its ideological propaganda wing to achieve the socio-educational goals?

\section{Significance}

This study gives primary attention to the form of ISIS's message as opposed to its content. This is because linguistic features are not randomly chosen, but are purposely used to reflect particular ideas. Thus, both content and form reflect ideology. Moreover, linguistic choices are ideologically invested. This means that the content and form are not mutually exclusive but they are codependent and mutually reinforcing.

\section{Purpose}

This study aimed at providing a brief overview of ISIS's ideology and origins as starting points for an analysis of its propaganda wing strategy. The study also attempts to illustrate precisely how ISIS's ideology is reflected through both content and form from a socio-educational perspective.

\section{Definitions}

\subsection{Sociology of terrorism}

Is an emerging subject in sociology attempting to comprehend terrorism as a social phenomenon and how people, as well as states, react to such events (Blain, 2009).

\subsection{Islamic State of Iraq and Syria (ISIS)}

Also known as "Daesh"; is a militant group and former unrecognized proto-state that follows a Salafi Jihadist doctrine. ISIS was established by Abu Musab Al-Zarqawi and attained global status in 2014 
when it drove Iraqi security forces out of key cities in its Western Iraq offensive (Schmid, 2015).

\subsection{Propaganda}

Is a particular synthesis or perception of manipulative information, often including both truths, as well as falsehoods for influencing attitudes and impacting the behavior of target audiences to engage in certain actions (Schmid, 2015).

\subsection{Dabiq}

Is an online magazine adopted by ISIS for Islamic radicalization and recruitment. It was first issued in July 2014 in various languages. Dabiq itself states the magazine is for the objectives of Unitarianism, truth-seeking, migration, holy war and community - tawhid, manhaj, hijrah, jihad, and jama'ah respectively (Fraser, 2014).

\section{Methodology}

For purposes of this study, an intrinsic case study is used to provide an overview of ISIS's key multilingual propaganda documents and media modes. It is these documents and modes of media that ISIS uses as primary sources for its propaganda strategy, which is employed through vocabulary reinforcement, in addition to piece-meal usage of Qur'an and Hadith.

\section{Literature Review}

It is important to note that all educational procedures may be accompanied by social procedures that reinforce the international community's perception of relative effects to the practices of ISIS's propaganda wing on youth in particular and society in general. Accordingly, in order to remedy this critical gap, the important necessity here is to become familiar with the different points of view on terrorism in the name of Islam and on its prevention in the socio-educational setting held by ISIS's propaganda wing.

In a study conducted on Islamic religion, teachers in Spain aimed to explore the points of view on terrorism in the name of Islam and to analyze the preventive socio-educational procedures that they suggest. The results of the study revealed that most of the teachers refer to a lack of knowledge of Islam among the young, especially concerning the concept of jihad, as the primary cause behind this phenomenon. Furthermore, the second-generation immigrants among the teachers attach considerable significance to possible identity crises as a reason that causes the young more vulnerable to violent radicalization. The study recommended the necessity of the promotion of preventive socioeducational strategies instead of emphasizing detecting expected violent extremists. In addition, it is emphasizing on teaching the fundamentals of the Islamic religion for providing young people with the tools that they require to deal with such violent ideologies (Navarro-Granados, et al., 2020).

In another study conducted by (Bisgin et al., 2019) explored ISIS's distinguished notorious from other terrorist groups relating to its Techniques, Tactics, and Methods. Thus, the study investigated the Dabiq magazine to explore propagandist factors by implementing natural language processing and text mining methods. The results of the study indicated that ISIS is highly capable of recruiting foreign fighters through its advanced "netwar" skills. Moreover, it showed that entities focused on the term "Jihad," and ISIS consistently looks to utilize the sources of Islam in their propaganda. Furthermore, the results indicated that there is a lack of a systematic analysis regarding the textual content. Nevertheless, ISIS's propaganda videos and images have been thoroughly investigated. The results also revealed that ISIS primarily targets Shiites by using insulting language about their belief system and trying to prove their attacks against them.

In a study aimed at investigating to what level ISIS is reinforcing its jihadist ideology on a 'cut- 
and-paste' or 'cherry-picked' version of Islam in their distinguished online propaganda magazine 'Dabiq'. The primary goal was to analyze systematically and quantitatively to what level ISIS uses the Qur'an in an atomistic, truncated, and tailored manner to reinforce its religious legitimacy. The results of the study indicated that a total of (15) issues of Dabiq and (70o) Qur'anic references were examined. Through a quantitative analysis, the study developed an innovative classification of Qur'anic chapters and verses (i.e. surahs and ayat, respectively) relied on their appearance in Dabiq. Moreover, the results revealed that the large-scale data analysis presents constant empirical evidence for extreme de-contextualization uses of the Qur'an in three ways: A thin, Medinan-dominated religious layer, ayah mutilation, and clustered versus exclusive mentions (Frissen et al., 2018).

Christien (2016) conducted a study aimed to analyze why ISIS uses youth in its propaganda and what roles of discourse help various representations of youth to convert a new generation of jihadi fighters. The study was a qualitative content analysis of the Dabiq magazine with immediate reference to Henry Giroux's theory of the myth of childhood innocence, which portrays youths as passive victims. The results of the study revealed that the progression of representations of youth in Dabiq aligns with this myth, as the publications point to provide active and violent roles for youth to foster further social paradigms.

Ingram (2016) conducted a study aimed at analyzing Dabiq magazine to investigate the strategic philosophy of ISIS calls to English-speaking Muslims. Through analyzing Dabiq's contents, the results of the study showed that Dabiq claims to its audiences by strategically designing an in-group identity, other solution, and crisis constructs which it leverages via value-, crisis- and dichotomy-bolstering narratives. Moreover, the results observed that ISIS provides its audiences with a powerful 'competitive system of meaning' that is created to form its readership's perceptions, polarize their support, and lead their radicalization by joining identity- and rational-choice claims.

Furthermore, Abumelhim, M. \& Abu-Melhim, A. (2015) conducted a study aimed to analyze the Critical Discourse Analysis (CDA) in ISIS's press releases as directed at Jordan in order to better understand both the sociolinguistic context in which ISIS operates and the socio-educational impact of these press releases. The results of the study concluded to decipher precisely how ISIS uses language to engage the Jordanian community in addition to the socio-educational effects of this language use.

\subsection{ISIS's ideology and origins}

ISIS is a literalist and dogmatic Salafi-jihadist organization (Olidort, 2015). This means that although the definitions of Salafism and Jihadism extend to include broader meanings than those, which underlie ISIS's ideology, its self-tailored understanding of these concepts fuels its fundamentalist approach to Sunni Islam. For example, while the term jihad includes meanings such as individual struggle against sin in addition to both violent and non-violent collective struggle against societal oppression, ISIS capitalizes divisively on the aspect of violent struggle to further its own purposes (Armborst, 2011). Likewise, while Salafism originated as a $19^{\text {th }}$-century solution to social problems based on the idea that a return to early Islamic social structures would solve society's ailments, ISIS approaches this concept dogmatically intending to prevent innovation within theology.

Structurally, ISIS has existed in its current form since April 8, 2013 - when it first officially expanded its operations from Iraq into Syria (MEMRI, 2013). Its roots, however, can be traced back to Jamaat Al-Tawhidwa-l-Jihad (JTWJ), 1999 - 2004. It has since evolved under different names, including Al-Qaeda in Iraq (AQI), 2004 - 2006, and even merged with other organizations under MajlisShura Al-Mujahedin (MSM), 2006, before becoming the Islamic State of Iraq (ISI, 2006) - the predecessor to its current form (Zelin, 2014).

ISIS's roots, however, cannot be traced in isolation. They must be understood, rather, within the backdrop of what has become its greatest competitor - Al-Qaeda, a terrorist organization well-known for its attacks targeting the West. This is not to say that these organizations' roots are identical, but it is to say that although the relationship between the two has recently developed into one of mistrust 
and hostility - as they compete for control of the international jihadist arena - ISIS originated from Al-Qaeda itself (Zelin, 2014). It is necessary, therefore, to trace the development of ISIS as an organization independent of Al-Qaeda by examining its differing background and aims.

Jamaat Al-Tawhid wa-l-Jihad (JTWJ) was founded with the aim of overthrowing Jordan and subsequently taking over the Levant (Douglas-Bowers and Corbett, 2014). Its founder - and thereby ISIS's "spiritual godfather," Abu Musab Al-Zarqawi (Worrall, 2015) - was a Jordanian hard-line Islamist from a poor socioeconomic background who as a young adult had committed various crimes resulting in sporadic jail time (Darwish, 2011). Ironically, the background of JTWJ's leadership and that of Al-Qaeda's were in stark contrast to one another. For example, while Zarqawi's entourage shared his background, Osama bin Laden - the former leader of Al-Qaeda - and the rest of AlQaeda's leadership had come from well-educated, upper-middle-class backgrounds. In fact, it was Zarqawi's criminal history coupled with his advocacy of Takfirism (which involves justifying the killing of other Muslims by accusing them of heresy) that originally created tension between him and bin Laden during their first meeting in 1999 in Afghanistan. Regardless of this tension, however, AlQaeda financed Zarqawi until 9/11, although Zarqawi had not yet given bay'a (allegiance) to bin Laden (Zelin, 2014).

The organizations were further distanced as a result of Zarqawi's leadership style during the war in Iraq - namely, his insistence that authority originates with fighters on the battlefront as opposed to theoretical masterminds far from the front lines, such as Al-Qaeda's leadership. It was not until he gave bay'a to bin Laden in October of 2004 (in what has been referred to as a "marriage of convenience," as this gave JTWJ "access to private donors and recruitment, logistics, and facilitation networks") that the tension between them subsided. It was at this point that Zarqawi's aim shifted to the establishment of an Islamic state under AQI (Al-Qaeda in Iraq). Zarqawi's leadership style persisted, however, as he became personally involved in beheadings and the coordination of suicide bombing missions against both Shias and Sunnis alike (Zelin, 2014). Thus, through his persistent engagement in indiscriminate violence, Zarqawi not only recreated tensions with Al-Qaeda's leadership but set the stage for ISIS's actions today. Indeed, ISIS is now infamous for public beheadings, crucifixions, and suicide bombing campaigns (CNN Library, 2014).

These tensions resulted in Zarqawi being reprimanded by Ayman Al-Zawahiri (former Al-Qaeda deputy head and its current leader) and Atiyat Allah Abd Al-Rahman Al-Libi (one of Al-Qaeda's former senior operations leaders / ideologues) and advised to reduce the amount of violence that his organization was engaged in. In fact, Al-Zawahiri and Al-Libi favored an institution-building approach, as they saw indiscriminate violence as being detrimental to the overall jihadist agenda in that it alienated the Sunni community. Although Zarqawi failed to decrease the violence committed by his organization, he would later adopt Zawahiri's advice on implementing an institution-building approach by establishing Majlis Shura Al-Mujahedin (MSM).

MSM was an umbrella group of like-minded organizations with Zarqawi in charge (Zelin, 2014). This group was short-lived, however, due to Zarqawi's death approximately six months later, but revamped as ISI (Islamic State of Iraq) in October of 2006. Interestingly, at this point, Zarqawi's replacement - Abu Hamza Al-Muhajir - gave bay'a to Abu Omar Al-Baghdadi, ISI's new leader by appointment (Lister, 2014). It is important to note that because only individuals, as opposed to organizations, can give bay'a, Zarqawi's death rendered null any previous allegiance to Al-Qaeda, leaving ISI to develop independently. Furthermore, this independence has been reinforced by the refusal of Abu Bakr Al-Baghdadi (Abu Omar Al-Baghdadi's successor and ISIS's current leader) to give bay'a to Al-Qaeda (Zelin, 2014).

Regardless of its independence from Al-Qaeda, however, ISIS remained little known even after it expanded its operations from Iraq into Syria in 2013, thereby becoming ISIS. In fact, it was not until it occupied Mosul that it became known as "indisputably the most effective and ruthless terrorist organization in the world" (Soufan Group, 2014). This occupation shocked conscientious observers of current events, who were blindsided by news of the Iraqi army fleeing Mosul alongside approximately half a million of its residents (Chulov et al., 2014). Little was it known then that what might have been 
considered just another random conflict situation in an already failing state (a failed state is one which is unable to provide proper services, including protection, to its citizens) would soon come to signify the beginning of a new era of human rights abuse (Chomsky, 2007).

While ISIS's occupation of Mosul was the catalyst that ushered in a new era of human rights abuse, this would not become clear to the international community until a little over two months later. It was at this point that ISIS released the first of what became a series of murder videos - that depicting the beheading of American freelance war correspondent James Foley (Carter, 2014). This is not to say that Foley's murder signaled the beginning of ISIS's abuse of human rights. Rather, it is to say that the release of this video was the defining point in which this abuse took center stage on a global platform. Since then, videotaped murders have become routine news pieces and the full spectrum of human rights abuse has been actualized at the hands of ISIS. Moreover, this has all occurred in the name of Islam (Abumelhim, 2021).

\subsection{ISIS's propaganda wing}

When ISIS existed in its previous form as the Islamic State of Iraq (ISI, 2006), it established Al-Furqan Foundation for Media Production. This media arm produced DVDs, CDs, pamphlets, posters, official press releases and online statements for the organization (Roggio, 2007). After rebranding itself as ISIS in 2013, ISIS created two more media arms. First, it created Al-I'tisam Media Foundation, which is ISIS's central distribution unit (Zelin, 2013a). Secondly, it created the Ajnad Foundation for Media Production, which specializes in audio releases and Nasheeds (Islamic songs chanted either to the background of percussion or acapella) (Zelin, 2013b). Finally, when ISIS occupied Mosul in 2014, it created Al-Hayat, which specifically targets Western recruits through the production of English, French, German, Russian and Turkish material (Gertz, 2014). Importantly, these four media arms (even Al-Furqan, which ISIS instituted before it took on its current form) are all currently active, lending extensive media experience to ISIS's extremely effective propaganda strategy.

\subsection{Dabiq in relation to other prominent Al-Hayat periodicals}

Al-Hayat itself has produced four prominent periodicals: Dabiq " referring to the countryside of Aleppo, Syria, where ISIS envisions Armageddon occurring”; Dar Al-Islam "House of Islam, referring to majority-Muslim areas which, ideally, are ruled by the shari'a and in which Islam can freely be practiced"; Konstantiniyye "Constantinople, referring to the fall of this central Byzantine (Eastern Roman Empire)city to Muslim Ottoman forces, who would rename it Istanbul"; and Rumiyah "Rome, referencing, again, the Roman Empire's fall”.

Dabiq was first released in July 2014 and is published in English, French, German, and Arabic (Harris, 2014). Its multi-lingual approach sheds light on its primary target audience, i.e. Western recruits. Moreover, Dabiq is a sophisticated propaganda magazine that discusses generic Islamic concepts such as jama'ah (community), jihad (holy war), hijrah (migration), minhaj (method), and tawhid (unity). It also contains articles / religious commentary and photo-reports highlighting ISIS's military successes. Importantly, Dabiq is unique from other prominent ISIS periodicals (which will be discussed below) in that it lays out the religious underpinnings of its version of a caliphate and provides religious argumentation to support its established political institutions. Thus, through Dabiq, ISIS portrays itself as being more than simply a terrorist organization (Gambhir, 2014).

Dar Al-Islam was first released in December 2014 and is published strictly in French (MEMRI, 2015). It focuses primarily on inciting lone-wolf attacks within France. Lone-wolf attacks are terrorist attacks prepared and carried out singlehandedly by individuals. Oftentimes, such attacks are executed without direct material support from global terrorist organizations, yet are influenced (whether through social media or propaganda tools such as those currently under discussion) by such organizations.

Konstantiniyye was first released in June 2015 and is published strictly in Turkish (Stein, 2015). It 
politically attacks the Turkish government (which is currently involved in the US-led coalition against ISIS), including Turkish President Recep Tayyip Erdogan. It also politically attacks the Kurdistan Workers' Party (PKK, which is based in Iraqi Kurdistan and is in conflict with ISIS militarily) and the Peoples' Democratic Party (HDP, a Turkey-based pro-minority, pro-Kurdish party).

Finally, Rumiyah (ISIS's newest periodical) was first released in September 2016 (McKernan, 2016). It is published in Uyghur, Indonesian, Russian, German, French, and English. Rumiyah is similar to Dabiq in that it highlights ISIS's military successes. However, it differs from Dabiq in that it also highlights ISIS's successes in influencing lone-wolf attacks in Western countries. In this regard, Rumiyah is similar to Dar Al-Islam. However, whereas Dar Al-Islam incites lone-wolf attacks specifically within France, Rumiyah makes a global call-to-arms in this regard. Comparing these prominent Al-Hayat periodicals helps clarify Dabiq's unique target audience and political, socioeducational recruiting aims.

\section{Results and Discussion}

It has been observed that ISIS is highly concentrated in exploiting the main sources of Islam (Qur'anic verses and Hadith) in its propaganda. Consequently, it has been noticed how narrative, imagery, and counter-narrative messaging are employed to form readers' impressions and polarize their support. The results of the study revealed that ISIS's ideology is reflected through both content and form from a socio-educational perspective by its propaganda wing strategy.

In Dabiq, Issue 1, ISIS systematically lays out religious argumentation for, and celebrates, its role in what it considers as the revival of the Islamic caliphate. First, it reports on Muhammad al-Adnani's (ISIS's former spokesperson) announcement of the caliphate and Al-Baghdadi's subsequent speech. Next, it publicizes its institution-building achievements between itself and the tribal leaders of the territories which it occupies. Specifically, these achievements involve the tribal leaders having given bay'a to Baghdadi.

Significantly, in discussing these achievements, ISIS not only highlights its military successes but also persuades its readers to make hijrah to its territory in order to give bay'a to Baghdadi in a manner similar to the tribal leaders. Thus, ISIS invites readers to invest themselves in the romantic idea of a restored golden age of Islamic civilization. ISIS then argues at length as to why its organization most imitates imamah (Islamic religious leadership). The precise manner in which it does will be illustrated through its usage of imamah to promote its ideology. Broadly speaking, however, ISIS uses this generic Islamic term to consolidate the power of Baghdadi by arguing that Islamic religious leadership involves both spiritual and political roles.

Finally, in Dabiq, Issue 1, ISIS outlines the details of Zarqawi's minhaj which ISIS itself has adopted. To recap, this minhaj includes migration, allegiance, listening, obedience and training, which lead to fighting, and then either the establishment of the caliphate or martyrdom (Harris, 2014).

Interestingly, ISIS markets Dabiq, Issue 1 as a dire response to the needs of the umma. It does this by crediting its success in initiating Dabiq to the readers' feedback that it received after releasing Islamic State News and Islamic State Report (Harris, 2014). These periodicals were newsletters / photo-bulletins that were released, at times, up to twice daily during the initial occupation of Mosul. Moreover, they later ceased production and became incorporated as specific sections within Dabiq itself. Interestingly, one counterterrorism analyst has pointed out that the incorporation of these periodicals into Dabiq not only helps ISIS to portray itself as being in-demand but also to retrospectively justify the soundness of its declaration of a caliphate. More specifically, having brought itself into direct confrontation with other jihadist organizations through the declaration of a caliphate - ISIS found that its ability to expand depended first on its ability to draw religious authority away from these organizations. In order to do this, ISIS had to prove that its minhaj was more legitimate and successful than theirs. For this reason, Dabiq, Issue 1 is uniquely rife with 
commentary from prominent jihadists such as Zarqawi and his mentor, al-Maqdisi (Gambhir, 2014). This brief overview of Dabiq, Issue 1 sets the stage for further research into ISIS's ideological promotion strategy, which could include analysis of ISIS's use of key Islamic texts and resources such as the Qur'an and Hadith (sayings of the Prophet).

ISIS's ideology shaped by Dabiq in particular; focused on some generic Islamic concepts used by ISIS which contain articles / religious commentary and photo-reports highlighting ISIS's military successes including the possibility of ISIS in attracting recruits, frightening opponents, and discrediting jihadist rivals.

Concerning Dar Al-Islam, ISIS's ideology focused primarily on inciting lone-wolf attacks within France. It also highlighted ISIS's military successes in influencing lone-wolf attacks in Western countries according to Rumiyah. Based on Konstantiniyye, ISIS's ideology also politically attacks the Turkish government including Turkish President Recep Tayyip Erdogan as well as attacks the Kurdistan Workers' Party and the Peoples' Democratic Party.

In conclusion, the findings showed the vital role of these periodicals in clarifying the priorities inherent in ISIS's unique ideology which aimed at developing and supporting ISIS's desired plans through its propaganda wing strategy including the possibility of drawing upon its findings to obtain ISIS's political, socio-educational recruiting aims and agendas.

\section{Conclusions}

Using an intrinsic case study to delineate ISIS's origins and undertaking a desk review of ISIS's most prominent propaganda mediums, this study systematically traced the roots of ISIS as a terrorist organization while giving an overview of the structure of its propaganda wing. Understanding the backdrop from which ISIS operates, including its history, will help those concerned with the global rise of terror to better understand how to mitigate ISIS's reemergence. Furthermore, in addition to providing an overview of ISIS's propaganda wing - including Al-Hayat Media Center - this study briefly compared Al-Hayat's most prominent periodicals with Dabiq to help serve to clarify Dabiq's unique target audience and political, socio-educational recruiting aims.

\section{References}

Abumelhim, M. (2021). The Abuse of Human Rights by Terrorist Organizations in the Name of Islam: A Case Study of the Islamic State of Iraq and Syria (ISIS). Journal of the Social Sciences, 50(1), 1-23.

Abumelhim, M. \& Abu-Melhim, A. (2015).The sociological impact of ISIS's press releases to Jordan: A Critical Discourse Analysis (CDA). British Journal of Humanities and Social Sciences, 13(2): 45-52.

Armborst, A. (2011). Salafi Jihadism and Jihadi Violence (Unpublished doctoral dissertation). Max Planck Institute for Foreign and International Criminal Law, Freiburg imBreisgau.

Bisgin, H., Arslan, H., \& Korkmaz, Y. (2019). Analyzing the Dabiq magazine: The language and the propaganda structure of ISIS. In International Conference on Social Computing, Behavioral-Cultural Modeling and Prediction and Behavior Representation in Modeling and Simulation, July 9 (pp. 1-11). Springer, Cham. https://doi.org/10.1007/978-3-030-21741-9_1

Blain, M. (2009). The Sociology of Terrorism: Studies in Power, Subjection, and Victimage Ritual. Boca Raton, FL: Universal-Publishers.

Carter, C. J. (2014, August 20). Video shows ISIS beheading US journalist James Foley. CNN. com, 9, p. 2017. Retrieved August 15, 2021, from https://edition.cnn.com/2014/o8/19/world/meast/isis-james-foley/index.html

Chomsky, N. (2007). Failed States: The Abuse of Power and the Assault on Democracy. Metropolitan Books.

Christien, A. (2016). The representation of youth in the Islamic State's propaganda magazine Dabiq. Contemporary Voices: St Andrews Journal of International Relations, 7(3): 1-8. http://doi.org/10.15664/jtr.1201

Chulov, M., Hawramy, F., \& Ackerman, S. (2014, June 12). Iraq army capitulates to Isis militants in four cities. The Guardian, 12. Retrieved August 15, 2021, from https://www.theguardian.com/world/2014/jun/11/mosul-isisgunmen-middle-east-states

CNN Library. (2014, August 08). ISIS fast facts. CNN. Retrieved August 15, 2021, from http://edition.cnn.com/2014/o8/o8/world/isis-fast-facts/ 
Darwish, A. (2011, October 23). Abu Musab Al-Zarqawi: Al-Qa'ida leader in Iraq who propagated his message by beheading hostages on video. The Independent. Retrieved August 15, 2021, from https://www.independent.co.uk/news/obituaries/abu-musab-Al-Zarqawi-481622.html

Douglas-Bowers, D. (Interviewer) \& Corbett, J. (Interviewee). (2014, October 24). ISIS and the Middle East: An interview with James Corbett [Interview transcript]. Retrieved August 15, 2021, from http://www.hamptoninstitution.org/isis-corbett-interview.html\#.WIxODBt97IU

Fraser, G. (2014, October 10). To Islamic State, Dabiq is important-but it's not the end of the world. The Guardian. Retrieved August 18, 2021, from https://www.theguardian.com/commentisfree/belief/2014/oct/10/islamicstate-dabiq-important-not-end-of-the-world

Frissen, T., Toguslu, E., Van Ostaeyen, P., \& d'Haenens, L. (2018). Capitalizing on the Koran to fuel online violent radicalization: A taxonomy of Koranic references in ISIS's Dabiq. Telematics and Informatics, 35(2): $491-503$. https://doi.org/10.1016/j.tele.2018.01.008

Gambhir, H. K. (2014). Dabiq: The strategic messaging of the Islamic State. Institute for the Study of War, 15(4): 1-12.

Gertz, B. (2014, June 03). New Al Qaeda group produces recruitment material for Americans, westerners. The Washington Free Beacon. Retrieved August 15, 2021, from http://freebeacon.com/nationalsecurity/new-AlQaeda-group-produces-recruitment-material-for-americanswesterners/

Harris, D. (2014). The Islamic State's (ISIS, ISIL) Magazine. The Clarion Project.

Ingram, H. J. (2016). An analysis of Islamic State's Dabiq magazine. Australian Journal of Political Science, 51(3): 458-477. https://doi.org/10.108o/10361146.2016.1174188

Lister, C. (2014). Profiling the Islamic State, Brookings Doha Center Analysis Paper, 1(13): 1-57.

McKernan, B. (2016, September 06). Isis' new magazine Rumiyah shows the terror group is 'struggling to adjust to losses'. The Independent. Retrieved August 18, 2021, from https://www.independent.co.uk/news/world/middleeast/isis-propaganda-terror-group-losses-syria-iraq-a7228286.html

Middle East Media Research Institute (MEMRI). (2015, November 16). In the words of the Islamic State: Understanding the rationale behind the November 13 Paris attacks. Jihad \& Terrorism Threat Monitor (JTTM), Inquiry \& Analysis Series. Retrieved August 18, 2021, from https://www.memri.org/jttm/wordsislamic-state-understanding-rationale-behind-november-13-paris-attacks

Middle East Media Research Institute (MEMRI). (2013, April o8). ISIS confirms that Jabhat Al-Nusrais its extension in Syria, declares' Islamic State of Iraq and Al-Sham' as new name of merged group. Jihad \& Terrorism Threat Monitor (JTTM). Retrieved August 15, 2021, from http://www.memri.org/report/en/o/o/o/o/o/o/7119.htm.

Navarro-Granados, M., Llorent-Bedmar, V., \&Cobano-Delgado Palma, V. C. (2020). The views on terrorism in the name of Islam held by Islamic religion teachers in Spain. Religions, 11(11): 624-64o.https://doi.org/10.3390/rel11110624

Olidort, J. (2015, November 24). What is Salafism? How a nonpolitical ideology became a political force. Foreign Affairs. Retrieved August 18, 2021, from https://www.foreignaffairs.com/articles/syria/2015-11-24/what-salafism

Roggio, B. (2007, October 28). US Targets al Qaeda's Al-Furqan Media Wing in Iraq. The Long War Journal. Retrieved August 18, 2021, from https://www.longwarjournal.org/archives/2007/10/us_targets_al_qaedas.php

Schmid, A. P. (2015). Challenging the narrative of the "Islamic State". The Hague: International Centre for CounterTerrorism, 1: 1-19.

Soufan Group. (2014, June 11). Dictatorship or takfirism: the new choice for the Middle East. Soufan Group. Retrieved August 18, 2021, from https://thesoufancenter.org/tsg-intelbrief-dictatorship-or-takfirism-thenew-choice-for-the-middle-east/

Stein, A. (2015, July 23). Turkey's returning fighter problem. Atlantic Council. Retrieved August 18, 2021, from http://www.atlanticcouncil.org/blogs/menasource/turkey-s-returning-fighter-problem

Worrall, S. (2015, September 30). ISIS wants to plant its black flags in Europe. Will it succeed? National Geographic. Retrieved August 18, 2021, fromhttps://www.nationalgeographic.com/adventure/article/150930-isis-booktalk-simon-worrall-terrorists-middle-east-syria-iraq

Zelin, A. Y. (2014). The war between ISIS and Al-Qaeda for supremacy of the global jihadist movement. The Washington Institute for Near East Policy, 20(1): 1-11.

Zelin, A. Y. (2013a, March o8). New statement from the Global Islamic media front: Announcement on the publishing of Al-I'tisam media foundation-a subsidiary of the Islamic State of Iraq-it will be released via GIMF. Jihadology. Retrieved August 18, 2021, from https://jihadology.net/2013/o3/o8/new-statement-fromthe-globAl-Islamic-media-front-announcement-on-the-publishing-of-al-iti\%E1\%B9\%Azam-mediafoundation-a-subsidiary-of-the-islamic-state-of-iraq-it-will-be-released-via-gimf/

Zelin, A. Y. (2013b, August 20). New statement from the Islamic State of Iraq and al-Shām: "Announcing Ajnād Foundation formedia production”. Jihadology. Recuperado de. Retrieved August 18, 2021, from http://jihadology.net/2013/o8/20/new-statement-from-the-islamic-state-of-iraqand-al-sham-announcingajnad-foundation-for-media-production/ 